\title{
PERIZINAN BERUSAHA MELALUI ONLINE SINGLE SUBMISSION SEBAGAI KETAATAN HUKUM DALAM RANGKA MENINGKATKAN INVESTASI
}

\author{
Seto Sanjoyo setosanjoyo16@gmail.com, ${ }^{1}$ \\ Sapriani zahrahyar@gmail.com, ${ }^{2}$ \\ Agus Setiawan setiawan.clorin@gmail.com, ${ }^{3}$ \\ Salma Suroyya salmasurroya@gmail.com ${ }^{4}$
}

\begin{abstract}
Abstrak
Online Single Submission (OSS) adalah sistem pengintegrasian perizinan usaha secara elektronik. Sistem ini memberikan layanan elektronik secara online system kepada investor/ pelaku usaha. Metode penelitian adalah penelitian hukum deksrptif empiris. Rumusan masalah kajian tulisan ini adalah bagaimanakah prosedur perizinan berusaha melalui sistem OSS dan apa akibat hukum bagi pelaku usaha apabila tidak memenuhi Komitmen Berusaha. Hasil penelitian ini menunjukkan bahwa prosedur perizinan melalui OSS memberikan kemudahan dan dapat diakses dimanapun berada, sehingga mempermudah investor dalam mengajukan izin. Ada tiga model yang ditawarkan bagi pelaku usaha dalam mengakses OSS yaitu sistem mandiri, pendampingan dan prioritas. Namun izin usaha yang sudah diberikan di awal kegiatan usaha dapat dibatalkan apabila pelaku usaha tidak memenuhi Komitmen berusaha dalam batas waktu yang telah ditentukan. Pernyataan Komitmen dari investor menjadi konsep kemudahan perizinan yang diberikan oleh sistem OSS. Pemenuhan komitmen pada izin usaha bersifat mutlak dan akan berakibat pencabutan izin usaha awal sehingga memberikan dampak investor tidak dapat melanjutkan usahanya.
\end{abstract}

Kata Kunci : Perizinan berusaha, investor, OSS

\begin{abstract}
Online Single Submission (OSS) is an electronic business licensing system. This system provides online electronic system services to investors / business people. The research method is empirical descriptive legal research. The formulation of the problem of this paper review is how the licensing procedure is attempted through the OSS system and what are the legal consequences for business actors if they do not meet the Business Commitment. The results of this study indicate that licensing procedures through OSS provide convenience and can be accessed wherever they are, making it easier for investors to apply for permits. There are three models offered for business people in accessing OSS, namely an independent system, assistance and priority. However, a business license that has been granted at the beginning of a business activity can be canceled if the business actor does not fulfill the business commitment within the specified time limit. Statement of Commitment from investors becomes the concept of licensing convenience provided by the OSS system. Fulfillment of the commitment to the business license is absolute and will result in the revocation of the initial business license so that the impact of investors can not continue their business.
\end{abstract}

Keyword : Business licensing, investors, OSS

\footnotetext{
${ }^{1}$ Aparatur Sipil Negara Pemerintah daerah Grobogan

2 Dosen Fakultas Hukum Universitas Borneo Tarakan

${ }^{3}$ Polisi Resort Ponorogo

4 Pejabat Pembuat Akta Tanah

64
} 


\section{A. PENDAHULUAN}

Era persaingan global memaksa semua negara untuk berlomba membangun dan memperkuat sistem perekonomian masing-masing. Indonesia sebagai salah satu negara yang sedang berjuang menarik investasi sebesar-besarnya untuk membangun sistem perekonomian nasional menghadapi tantangan yang sama di tengah persaingan tersebut. Dalam rangka merespon tantangan tersebut pemerintah Indonesia secara terus-menerus berupaya untuk menaikkan peringkat kemudahan berusaha. ${ }^{5}$ Laporan World Bank mengenai indeks kemudahan berusaha atau Ease of Doing Business (EoDB) 2020 menyatakan peringkat Indonesia masih stagnan dibandingkan tahun sebelumnya di posisi 73 dari 190 negara. Saat ini ada ribuan peraturan daerah dan peraturan menteri yang sedang dievaluasi dan akan dicabut, terakhir ada sekitar 40 peraturan menteri yang diinstruksikan oleh Presiden Joko Widodo untuk dicabut selambatlambatnya Desember 2019 karena dianggap menghambat investasi. Hal tersebut dimaksudkan untuk mengejar ketertinggalan Indonesia dalam kemudahan layanan perizinan dari negara-negara tetangga seperti Vietnam, Malaysia, dan Singapura. Selanjutnya, memberikan kewenangan sepenuhnya kepada Badan Koordinasi Penanaman Modal (BKPM) untuk pengaturan dan pengurusan perizinan, termasuk mengevaluasi perda-perda terkait izin.

Indonesia merupakan salah satu Negara tujuan investasi yang sangat strategis bagi investor baik dalam negeri maupun luar negeri. Meningkatnya daya saing Indonesia di tingkat dunia didukung keberadaan sumber daya alam yang melimpah baik hayati maupun non hayati, tenaga kerja yang terampil dan produktif, pasar domestik yang terus berkembang dan dukungan positif dari pemerintah. Selain itu, iklim politik Indonesia yang relatif stabil sebagai Negara demokrasi yang mampu menyatukan berbagai ragam suku, agama, ras dan adat istiadat menjadikan Indonesia semakin menarik dan kondusif sebagai tujuan investasi.

Pada perspektif di lapangan, melimpahnya sumber daya baik hayati maupun non hayati tersebut ternyata belum mampu mengoptimalkan pemasukan investasi bagi Indonesia. Salah satu hal yang dianggap menghambat perkembangan dan optimalisasi investasi adalah mengenai kebijakan hukum perizinan. Perizinan yang diberlakukan kurang memiliki keberpihakan pada investor baik dari segi waktu yang relatif panjang dan menguras tenaga maupun nominal biaya yang harus dikeluarkan dalam pengurusan perizinan tersebut. Sementara tanpa mengantongi perizinan, maka para investor tidak akan bisa menginvestasikan modalnya di Indonesia. ${ }^{6}$

Sejalan dengan hal tersebut dalam Visi dan Arah Pembangunan Jangka Panjang Indonesia 2005-2025 khususnya dalam bidang Hukum menginginkan adanya penyederhanaan syarat dan prosedur dalam penerbitan berbagai perizinan. Untuk melaksanakan harapan tersebut salah satu upaya yang dilakukan oleh Pemerintah adalah dengan membuat paket kebijakan deregulasi dan reregulasi terhadap peraturan perundang-undangan yang dianggap tidak mendukung investasi, utamanya bidang perizinan.

${ }^{5}$ Arfan Faiz Muhlizi, 2017, Penataan Regulasi Dalam Mendukung Pembangunan Nasional, Jurnal Rechtsvinding Vol. 6 No. 3, Badan Pembinaan Hukum Nasional, Jakarta, h. 340

${ }^{6}$ Galuh Wahyu Kumalasari, 2017, Penegakan Hukum Perizinan Sebagai Instrumen Penguatan Investasi sektor ekonomi Kreatif Guna Meningkatkan Kesejahteraan Masyarakat, Makalah Seminar Nasional dengan tema "Perizinan sebagai Instrumen Peningkatan Kesejahteraan Masyarakat di Era Industrialisasi" yang dilaksanakan Universitas Muhammadiyah Surakarta pada tanggal 29 April 2017, h. 225 
Salah satu bentuk komitmen pemerintah dalam meningkatkan peringkat kemudahan berusaha di Indonesia adalah dengan menerbitkan Perpres No. 91 Tahun 2017 tentang Percepatan Pelaksanaan Berusaha, dilanjutkan dengan Peraturan Pemerintah Nomor 24 Tahun 2018 tentang Pelayanan Perizinan Berusaha Terintegrasi Secara Elektronik atau Online Single Submission (OSS). Pasca mulai diimplementasikannya OSS sebagai sarana penunjang ease of doing business (EODB) ternyata memberikan pengaruh yang sangat signifikan untuk memberikan kemudahan perizinan di Negara Indonesia. Mendasarkan pada data yang dikeluarkan Bank Dunia sejak diimplementasikannya OSS indicator starting a business mengalami kenaikan peringkat, dari level 144 menjadi 134 atau naik 10 tangga. Walaupun pemeringkatan EODB negara kita dalam paparan Doing Business 2019 mengalami penurunan 1 level, pada tahun ini level 73 padahal di tahun kemarin 72, berbanding terbalik indeks EODB Indonesia mengalami kenaikan menjadi 67,96 atau naik 1,42 dibandingkan tahun sebelumnya.

Masalahnya kemudian apakah konsep perizinan berusaha melalui sistem OSS yang ditawarkan tersebut mampu memberikan jaminan kepastian hukum dan kemudahan berinvestasi sekaligus juga memberikan manfaat bagi sebesar-besarnya kemakmuran rakyat maupun bagi lingkungan? Terlebih sistem OSS terkait erat dengan penggunaan teknologi internet. Sangat disadari pula bahwa tidak semua warga masyarakat yang akan melaksanakn usaha (menjadi pelaku usaha) mampu menggunakan teknologi internet, atau mereka yang memiliki modal sangat besar tetapi tidak memiliki waktu untuk tetek bengek terkait birokrasi perizinan, akhirnya cenderung apatis. Dalam konteks ini maka adalah wajar jika mereka mendapatkan prioritas pelayanan, termasuk juga bagi para pelaku usaha yang memiliki keterbatasan secara fisik (difabel), ataupun mereka yang sudah lanjut usia.

\section{B. METODE PENULISAN DAN RUMUSAN MASALAH}

Metode dalam penulisan ini yaitu deskriptif empiris dengan menjelaskan pelaksanaan perizinan dan akibat yang ditimbulkan dalam pemenuhan komitmen perizinan. Melihat berbagai permasalahan di atas, maka dapat diambil beberapa identifikasi masalah sebagai berikut:

1. Bagaimanakah prosedur perizinan berusaha melalui sistem OSS?

2 Apa akibat hukum bagi pelaku usaha apabila tidak memenuhi Komitmen Berusaha ?

\section{PEMBAHASAN}

Hukum memberikan rasa nyaman pada masyarakat dengan cara mengatur dan terdapat sanksi bila yang melanggar, sehingga tidak terjadi kebingungan dalam berrtindak, berperilaku dan berinteraksi. Hukum bisa berlaku bila sudah terdapat prosedur hukum untuk melaksanakannya. Hukum akan berlaku dan dapat diterapkan jika sudah terdapat kepastian hukum. ${ }^{7}$ Setiap kegiatan ekonomi perlu dukungan hukum, karena tanpa dukungan hukum yang memadai dapat memunculkan ketiadaan kepastian hukum, tentunya akan berdampak bagi kegiatan ekonomi itu sendiri. Kepastian hukum dapat memberikan rasa percaya bagi setiap pelaku ekonomi, karena pelaku ekonomi dapat memprediksi keuntungan yang diharapkan. Apabila keuntungan dapat diprediksi dengan jaminan kepastian hukum, maka bagi pelaku bisnis akan mudah untuk mengambil keputusan investasinya. Dukungan hukum bagi kegiatan ekonomi dapat

${ }^{7}$ Bernard L. Tanya ( et.al), Teori Hukum, Genta Publishing, Cet. ke-3, 2010,hal, 128- 132 
diwujudkan dari proses produksi sampai proses distribusi, bahkan sampai pemberian perlindungan bagi konsumen.

Richard A. Posner mengemukakan bahwa hukum seharusnya mempromosikan efisiensi dan menggunakan analisis social wealth maximization untuk mencari sintesis theoremanya. Melalui kajian dalam bukunya yang bertajuk "Frontiers of Legal Theory", Posner meneliti aspek heuristic dan descriptive dari analisis ekonomi dalam hukum. Aspek heuristic ingin mengkaji kesatuan antara doktrin hukum dengan institusi hukum. Sementara aspek descriptive berusaha mencari logika ekonomi yang memengaruhi doktrin dan institusi hukum hingga mengakibatkan perubahan hukum. ${ }^{8}$

Mencermati hubungan prinsip ekonomi yang mempengaruhi doktrin hukum terhadap institusi hukum hingga mengakibatkan perubahan hukum dalam aspek descriptive Posner, dapat dijelaskan bahwa kebutuhan investasi menuntut inovasi negara untuk memberikan kemudahan dalam berusaha utamanya kemudahan dalam memperoleh perizinan berusaha dengan membangun lembaga Online Single Submission (OSS). Kebijakan pemberian perizinan berusaha yang diberikan di awal memungkinkan pelaku usaha membangun kegiatan usahanya baru kemudian memenuhi persyaratan izinnya. Hal ini dimungkinkan dengan kewajiban membuat dan menandatangani Komitmen Berusaha. Di sisi lain, apabila komitmen berusaha sebagai persyaratan dalam pemberian perizinan berusaha sementara tidak dipenuhi, maka izin usaha tadi akan dicabut, dan kegiatan usaha yang telah berjalan menjadi illegal.

Selanjutnya konsep Wealth Maximization dari teori analisis ekonomi dalam hukum Posner, menfokuskan diri pada penerapan prinsip efisien dan efektifitas. Dalam hal ini Posner menterjemahkan efisien sebagai suatu keadaan yang sumber dayanya dialokasikan sehingga nilainya (value) maksimal. Aanalisis perekonomian, efisiensi diutamakan pada kepatutan atau etika dalam membuat keputusan-keputusan sosial (social decision making) yang memberikan dampak pada pengaturan kesejahteraan masyarakat. 9

Investasi sebagai salah satu kegiatan ekonomi, telah menjadi komoditas penting bagi perekonomian suatu negara. Secara langsung, investasi mampu menggerakkan sektor-sektor ekonomi, penciptaan lapangan pekerjaan, memungkinkan transfer teknologi hingga mendorong pertumbuhan ekonomi.10 Namun, dalam proses pembangunan ekonomi, hukum diharapkan menjadi panglima untuk semua aspek kehidupan bermasyarakat, berbangsa dan bernegara. Ketika terjadi pertentangan kepentingan antara privat (individu) dan masyarakat (kelompok) dengan kepentingan publik, maka yang dapat disepakati adalah prinsip pengutamaan kepentingan publik yang disertai penghormatan terhadap hak-hak individual. Selain itu, bahwa politik hukum dalam hukum ekonomi diarahkan untuk mencapai kemakmuran bersama, dengan tujuan tertingginya adalah untuk kebahagiaan dan kesejahteraan bersama.

Dalam konteks investasi, sekecil apapun investasi yang ditanam haruslah memberikan hasil (laba) bagi investor. Di era tahun 70-an muncul pemikiran-pemikiran baru bahwa yang bisa mengatasi perang dalam ekonomi adalah hukum yang kemudian melahirkan konsep law as a tool of economic engineering. Mochtar Kusumaatmadja

8 Muhammad Rustamaji, 2013, Menakar Pengawasan Pemberian Bantuan Hukum Dalam Pandangan Richard A Posner, Jurnal Rechtsvinding, Vol. 2 No. 1, April 2013, Badan Pembinaan Hukum Nasional, Jakarta, h. 99

${ }^{9}$ Muhammad Rustamaji, Op.Cit., h.102

10 Aviliani, 2010, Mengurai Problema Investasi di Idonesia, Jurnal Diplomasi, Vol. 2 No. 2, Kementerian Luar Negeri, Jakarta, h. 37 
mendefinisikan law as a tool of economic engineering bahwa hukum merupakan sarana untuk melakukan rekayasa di bidang perekonomian. Model bekerjanya hukum disini pertama, hukum harus bisa menjadi faktor akselerasi (percepatan) kemajuan ekonomi. Kedua, hukum harus bisa mengamankan hasil-hasil pembangunan ekonomi, dengan prinsip efektifitas dan efisiensi.

Dasar pengembangan hukum ekonomi adalah Pasal 33 UUD NRI 1945 hasil Amandemen Keempat mengatakan:

(1) Perekonomian disusun sebagai usaha bersama berdasar atas asas kekeluargaan;

(2) Cabang-cabang produksi yang penting bagi negara dan yang menguasai hajat hidup orang banyak dikuasai oleh negara;

(3) Bumi dan air dan kekayaan alam yang terkandung di dalamnya dikuasai oleh negara dan dipergunakan untuk sebesar-besar kemakmuran rakyat;

(4) Perekonomian nasional diselenggarakan berdasar atas demokrasi ekonomi dengan prinsip kebersamaan, efisiensi, berkeadilan, berkelanjutan, berwawasan lingkungan, kemandirian, serta dengan menjaga keseimbangan kemajuan dan kesatuan ekonomi nasional.

(5) Ketentuan lebih lanjut mengenai pelaksanaaan pasal ini diatur dalam undangundang.

Perkembangan investasi di Indonesia dimulai dengan terbitnya Undang-Undang Penanaman Modal Asing (PMA) Nomor 1 Tahun 1967, pada era Presiden Soeharto. Presiden Soeharto dengan kebijakan ini melegalkan berbagai eksploitasi di Indonesia, terutama eksploitasi di bidang kekayaan alam (mineral). Era tahun1967, Indonesia sudah membuka untuk pemodalan asing dengan jangka waktu setiap kontrak sampai dengan 30 (tiga puluh) tahun. Implementasi regulasi ini mulai tumbuh perusahaanperusahaan tambang dari negara barat terutama negara adikuasa Amerika. Perusahaan tambang PT. Freeport di Pulau Papua dan pertambangan emas oleh PT. Newmont di Nusa Tenggara Barat. Pertambangan emas di Papua oleh perusahaan Amerika atas kesepakatan antara Pemerintah Indonesia dan Amerika dalam jangka waktu yang panjang, selama 30 tahun semenjak tahun 1967 dan akan berakhir pada 1997. Tahun 1991 menjadi titik nadir sektor pertambangan dimana pada tahun ini, pemerintah menyepakati perpanjangan kembali perijinan eksploitasi emas di Papua selama 30 tahun kedepan ditambah dua kali sepuluh tahun dengan dalih untuk pengembangan Papua. Komitmen Indonesia untuk memajukan dan memperadabkan Papua juga menjadi kewajiban Amerika sesuai dengan isi kesepakatan perpanjangan ijin ini. ${ }^{11}$

Tahun 1968 juga lahir Undang-Undang Nomor 6 Tahun 1968 tentang Penanaman Modal Dalam Negeri (PMDN). Produk hukum ini juga lahir pada era Presiden Soeharto untuk penyeimbangan atas regulasi penanaman modal asing. Pasal 3 ayat (1) memberikan izin kepada investor asing berusaha pada unsur-unsur produksi yang dapat menguasai hajat hidup orang banyak itu dengan syarat besaran modal asing tidak melebihi 49\%. Namun terdapat kebijakan terkait nilai kuantitas investor Indonesia sebesar 51\% itu harus dinaikkan sampai 75\% tidak boleh berkurang dari tahun $1974 .^{12}$

Pada masa reformasi, hukum investasi di Indonesia digabungkan menjadi menjadi satu antara regulasi penanaman modal asing dan penanaman modal dalam negeri dengan lahirnya Undang-Undang Nomor 25 Tahun 2007 tentang Penanaman Modal.

${ }^{11}$ Salim HS dan Budi Sutrisno, 2018, Hukum Investasi di Indonesia, Raja Grafindo Persada, Depok, h. 1 , 
Undang-Undang ini memiliki beberapa pasal yang secara jelas mengatur hukum atau aturan investasi di Indonesia. Penggabungan regulasi antara Penanaman Modal Asing dan Penanaman Modal Dalam Negeri mengandung makna berikut:13

1. Berdasarkan UUD Negara Republik Indonesia Tahun 1945. Berdasarkan konstitusi ini, untuk membuat perekonomian Indonesia lebih baik maka perlu menetapkan suatu tujuan dengan membuat perencanaan pembangunan ekonomi nasional kedepannya secara berkelnjutan kesinambungan. Pembangunan ekonomi harus dilandaskan pada demokrasi ekonomi pancasila sebagai falsafah hidup bangsa;

2. Menegakkan perintah yang sudah diamanatkan di TAP MPR Indonesia Nomor XVI/MPR/1998. Tekait semua kebijakan penanaman modal harus dilandaskan pada sistem perekonomian kerakyatan. Pengaturan perekonomian kerakyatan terdapat UMKM (Usaha Mikro, Kecil dan Menengah) serta koperasi sebagai soko guru perekonomian Indonesia;

3. Dalam rangka penyegeraan pembangunan ekonomi, segera melakukan usaha peningkatan penanaman modal. Usaha ini dimaksudkan untuk mengelola dan mengeksplorasi potensi ekonomi menjadi suatu potensi yang riil dan dapat dinikmati untuk pembangunan negara secara nyata.

4. Pembangunan iklim investasi di Indonesia harus dibangun sebagai upaya menjaga kerjasama secara global. Bersifat promotif, adil, serta kondusif kedaaan polhukkam dalam negeri untuk mencapai efisien Iklim investasi. Iklim investasi harus sejalan dengan laju pembangunan ekonomi nasional.

Pemberlakuan Undang-Undang No. 25 Tahun 2007 bertujuan untuk memberikan gambaran pembangunan ekonomi secara nasional dengan dilandaskan prinsip demokrasi sebagai bentuk kedaulatan perekonomian Indonesia yang tidak dapat diintervensi oleh asing. Keterkaitan dengan pembangunan ekonomi dipertegas lagi dalam TAP MPR RI No XVI/MPR/1998 tentang PolitiK Hukum Ekonomi Dalam Rangka Demokrasi Ekonomi sebagai sumber hukum materiil. Penguatan sektor ekonomi dalam rangka penanaman modal utamanya usaha mikro, kecil, menegah, serta koperasi menjadi landasan kebijakan penanaman modal di Indonesia.

Sebagai upaya mendukung kepastian hukum usaha terkait hal di atas, pemerintah telah mengundangkan Peraturan Presiden No. 91 Tahun 2017 tentang Percepatan Pelaksanaan Berusaha. Upaya dalam memberikan kecepatan pelaksanaan usaha dibagi dalam 2 tahap sebagai berikut:

Tahap I: (1) Membentuk Satuan Tugas (Satgas) sebagai upaya dalam memberikan pengawalan dan menyelesaikanhambatan dan permasalahan dalam melaksanakan usaha (end to end); (2) pemberian perizinan dengan syarat yang harus dipenuhi (checklist) pada Kawasan Perdagangan Bebas, Kawasan Industri, Pelabuhan Bebas (KPBPB), Kawasan Strategis Pariwisata Nasional (KSPN) dan Kawasan Ekonomi Khusus (KEK) yang telah dikelola dan berjalan; (3). Pelaksanaan pembagian data diluar jangkauan kawasan yang telah berjalan.

Tahap II: (1) Melaksanakan perubahan perizinan berusaha dengan menerapkan penyederhanaan izin berusaha; dan (2) Penerapan pengintegrasian perizinan dalam satu sistem (Online Single Submission) dan pelaksanaannya bersama dengan pelayanan PTSP dalam satu gedung hingga Mei 2018. Peranan Satgas pada tingkat atas samapai 
bawah dari tingkat nasional sampai ketingkat daerah (level kabupaten/kota) memiliki urgensi dalam mengidentifikasi dan menyelesaikan masalah di bidang investasi.

\section{C.1. Prosedur Memperoleh Perizinan Berusaha Melalui Sistem Online Single Submission (OSS)}

Selama ini perizinan hanya dilihat dari sisi negatif, dimana izin dianggap menyusahkan pengusaha, berbiaya mahal, pengurusannya lama dan berbelit-belit, dan sebagainya. Padahal fungsi izin tidak semata-mata untuk memberikan masukan dan tambahan bagi keuangan negara atau daerah, tetapi juga ada fungsi kontrol, pembinaan, pemberdayaan, pengawasan, kepastian berusaha dan fungsi-fungsi lain yang tetap harus dipertahankan. Paling tidak fungsi izin meliputi 4 hal yaitu untuk mengendalikan atau mengarahkan aktivitas tertentu, mencegah bahaya bagi lingkungan, melindungi obyekobyek tertentu, membagi benda yang sedikit, dan/atau mengarahkan atau menyeleksi orang. Sehingga izin tetap dibutuhkan pada kegiatan usaha masyarakat. Oleh sebab itu, meniadakan sama sekali izin bagi setiap kegiatan usaha (investasi) adalah suatu kemusykilan.

Perizinan dilaksanakan untuk memberikan legal formal kepada orang perorangan atau badan usaha/badan hukum tertentu, berupa tanda daftar usaha maupun dalam bentuk perizinan. Perizinan merupakan salah satu dari beberapa parameter yang paling sering dipakai dalam hukum administrasi, ${ }^{14}$ sebagai pengendali perbuatan masyarakat. Perizinan merupakan hal yang sangat penting dalam memulai semua jenis usaha.

Pengusaha diwajibkan mengurus izin awal usahanya dengan melakukan pendaftaran bentuk dan jenis usahanya untuk memperoleh izin sebagai modal hukum pelaksanaan bisnis usaha perdagangan yang dilakukan. Perizinan untuk melaksanakan perdagangan yang dimohonkan pengusaha yang selanjutnya disebut SIUP, merupakan dokumen perizinan yang harus dimiliki oleh pengusaha maupun badan usaha bentuk lain sebagai syarat wajib usaha perdagangan. SIUP wajib dimiliki semua pengusaha baik dalam skala kecil maupun skala besar. Berdasarkan modal yang dijadikan syarat awal dalam mendirikan usaha, SIUP dapat dikelompokkan menjadi tiga kategori, yaitu :

1. SIUP Besar : Diperuntukkan bagi perusahaan yang memiliki modal usaha diatas Rp. $500.000 .000,-$

2. SIUP Menengah : Diperuntukkan bagi pengusaha/ perusahaan yang memiliki modal antara Rp. 200.000.000,- sd Rp. 500.000.000,-

3. SIUP Kecil : diperuntukkan bagi pengusaha/ perusahaan yang memiliki modal lebih kecil atau sama dengan Rp. 200.000.000,-

Mengurus SIUP saat belum adanya Unit atua Dinas Pelayanan Terpadu Satu Pintu dilakukan di Kantor Dinas Perdagangan di tingkat kabupaten/kotamadya ataupun di Kantor Pelayanan Perizinan Setempat. Keharusan administratif untuk pengurusan SIUP dipisah-pisahkan berdasarkan bentuk usaha maupun jenis usaha yang akan dijalankan, untuk pemisahannya yaitu:

1. Perseroan Terbatas ( PT)

- Duplikat KTP dalam bentuk fotocopy pemilik dari usaha

- Duplikat KK dalam bentuk fotocopy pemilik dari usaha

- Duplikat NPWP Perusahaan

${ }_{14}$ Philipus M. Hadjon, 1993, Pengantar Hukum Perizinan, Yuridika, Fakultas Hukum Universitas Airlangga, Surabaya, h. 2-3 
- Surat Keterangan Domisili

- Akta Pendirian PT yang telah difotocopy

- Surat Keputusan Pengesahan Badan Hukum yang telah difotocopy dari Menteri Hukum dan HAM

- NIB (Nomor Induk berusaha)

- Neraca Perusahaan

- Foto berukuran 4 x 6 sebanyak 2 lembar pemilik perusahaan

- Materai Rp. 6.000 ,-

2. Koperasi

- Duplikat KTP dalam bentuk fotocopy Dewan Pengurus dan Dewan Pengawas Koperasi

- Duplikat NPWP dalam bentuk fotocopy

- Duplikat Akta Pendirian Koperasi dalam bentuk fotocopy yang dilegalisir

- Daftar susunan Dewan Pengurus dan Dewan Pengawas

- Fotocopy surat keterangan domisili dari Pemerintah Daerah

- Neraca Koperasi

- Materai senilai Rp. 6.000 ,-

- Pas foto ukuran 4 x 6 sebanyak 2 lembar. Izin lain yang terkait (misalkan jika usaha menghasilkan limbah, harus memiliki izin AMDAL dari Badan Pengendalian Dampak Lingkungan Daerah setempat)

3. Perusahaan Perseorangan

- Duplikat KTP dalam bentuk fotocopy pemilik dari usaha

- Duplikat NPWP dalam bentuk fotocopy

- Surat Keterangan Domisili

- Neraca Perusahaan

- Materai senilai Rp. 6.000 ,-

4. Perusahaan Perseroan Terbuka ( Tbk)

- Duplikat KTP dalam bentuk fotocopy pemilik dari usaha

- Duplikat SIUP dalam bentuk fotocopy pemilik dari usaha sebelum menjadi Perseroan Terbuka

- Fotocopy Akta Notaris Pendirian dan perubahan perusahaan dan surat persetujuan status perseroan tertutup menjadi perseroan terbuka dari Departemen/Kementerian Hukum dan HAM

- Surat keterangan dari Badan Pengawas Pasar Modal bahwa perusahaan tersebut telah melakukan penawaran umum secara luas dan terbuka

- Fotocopy surat tanda penerimaan laporan keuangan tahunan perusahaan (STP LKTP) tahun bulan terakhir

- Pas foto pemilik perusahaan ukuran 4 x 6 sebanyak 2 lembar 
Penerbitan SIUP biasanya sekitar dua minggu, biasanya pemilik SIUP akan dihubungi oleh petugas untuk mengambil, ataupun pihak pemilik bisa datang ke kantor pembuatan perizinan tersebut.

Online Single Submission (OSS) merupakan program rekontruksi sistem pelayanan perizinan yang pernah dilakukan pada kantor Pelayanan Terpadu Satu Pintu (PTSP) berdasarkan Pasal 25 ayat (4) Undang-Undang No. 25 Tahun 2007. OSS diatur dalam Peraturan Pemerintah No. 24 Tahun 2018 tentang pelayanan perizinan berusaha terintegrasi secara elektronik. OSS adalah pengintegrasian perizinan berusaha secara elektronik pelayanan perizinan dengan tujuan meningkatan dan permodalan dan usaha. Dimana izin prinsip penanaman modal dalam perizinan digantikan oleh Nomor Induk Berusaha (NIB) yang memiliki fungsi sebagai Tanda Daftar Perusahaan (TDP). Kementerian serta pemerintah daerah tidak mempunyai kewenangan untuk penerbitan izin, sehingga penerbitan pengintegrasian berusaha secara elektronik ditangani oleh kementerian koordinator bidang perekonomian (Kemenko Perekonomian) sebagai koordinator.

Bentuk pelayanan yang difokuskan pada restrukturisasi perizinan, pendampingan (end to end), dan pengawalan dan percepatan penyelesaian hambatan melalui pembuatan satuan tugas (Satgas) pada tingkatan yang berjenjang dari pusat sampai daerah. Pelayanan perizinan bersifat sama dan merata, tidak membeda-bedakan antara pengusaha besar dan pengusha kecil, antara keluarga pejabat dan masyarakat biasa, serta antara pengusaha pribadi maupun badan usaha dan badan hukum. Keadilan dimulai dengan pilihan utama yang disepakati secara bersama. Hukum dibuat atas kesepakatan dan berlaku tanpa membeda-bedakan orang dengan orang, kelompok dengan orang, dan kelompok dengan kelompok. ${ }^{15}$ Dalam konteks tersebut sistem OSS diciptakan untuk memenuhi adanya kesetaraan dan keadilan tidak membeda-bedakan orang atau badan usaha.

Sistem OSS ini meciptakan permaslahan apabila pemerintah daerah (provinsi atau kabupaten/kota) belum menjalankan sistem Perijinan Terpadu Satu Atap (PTSP). Beberapa pemerintah provini dan pemerintah kabupaten/kota di Indonesia ada yang terlambat atau bahkan belum sama sekali melaksanakan sistem perijinan satu atap, tentu saja dapat menghambat pengurusan perizinan. Selain itu sistem ini juga akan siasia apabila BKPM tidak melaksanakan fungsi koordinasi dengan pemerintah daerah dari provinsi hingga kabupaten. Sistem ini akan memberikan jalan yang mulus bagi perizinan investasi bermodal besar dan adanya pengaruh langsung dengan pemerintah pusat, tetapi bila untuk perusahaan swasta yang tidak memiliki korelasi dengan pemerintah secara langsung akan mengalami kesulitan dalam implementasinya.

Proses perizinan usaha menggunakan OSS, perorangan atau perusahaan cukup membuka website www.oss.go.id, pemohon mengajukan proses perizinan usahanya dengan mengisi isian yang sudah terdapat dalam menu OSS. Membuka website ini, tidak harus datang ke kantor Dinas Penanaman Modal dan Pelayanan Terpadu Satu Pintu atau ke kantor PTSP di tingkat kementerian, tapi bisa diakses oleh pemohon dimanapun berada. Kepemilikan badan usaha dan badan hukum yang sudah didaftarkan di Notaris, Nomor Pokok Wajib Pajak (NPWP) serta Nomor Induk Kependudukan (NIK) oleh penanggungjawab perusahaan untuk didaftarkan akan memperoleh Nomor Induk Berusaha (NIB) dari sistem OSS.

15 John Rawls, 2019, Teori Keadilan Dasar-Dasar Filsafat Politik untuk Mewujudkan Kesejahteraan Sosial dalam Negara, Pustaka Pelajar, Jakarta, h. 14 
Sistem OSS ini juga memberikan kemudahan bisa diakses kapanpun tidak dibatasi waktu, pemohon bisa melakukannya 24 jam. Permohonan sistem ini juga tidak dipungut biaya sama sekali, sehingga memenuhi azas kemudahan, efisiensi dan murah. Pemohon juga bisa mencetak sendiri Nomor Induk Berusaha tanpa harus datang di kantor pemberi layanan perizinan. Kantor PTSP akan memberikan pendampingan kepada masyarakat jika mengalami permasalahan dalam menginput data. Prinsip pelayanan yang diharapkan memberikan akselerasi kecepatan dalam pelayanan dan kepastian hukum kepada masyarakat dapat mendukung pertumbuhan ekonomi.

Nomor Induk Berusaha sebagai pengganti ijin prinsip, untuk usaha kecil dalam mengajukan SIUP tidak perlu lagi dalam pemenuhan komitmen. Pengusaha kecil dalam mengajukan perizinan usahanya hanya bermodalkan Kartu Tanda Penduduk yang mempunyai Nomor Induk Kependudukan valid, dimasukkan melalui sistem OSS, setelah dilaksanakan input data dan terverifikasi oleh sistem, maka ijin langsung keluar tanpa ada izin tambahan dan biaya lain yang dapat menjadikan beban pengusaha Kecil. Sistem ini memberikan kepastian hukum berusaha, dan sangat melindungi kepada pengusaha kecil, karena sangat dipermudah dalam persyaratannya.

Prosedur dan cara untuk mengakses OSS lumayan gampang. Pengusaha datang ke Pelayanan Terpadu Satu Pintu (PTSP) dengan membawa permohonan izin cukup membawa akta notaris yang ada di Dinas Penanaman Modal dan Pelayanan Terpadu Satu Pintu (DPMPTSP) provinsi atau kabupaten/kota, juga PTSP yang sudah dimiliki kementerian/lembaga terkait. Pemohon nantinya akan dipandu oleh petugas PTSP untuk mengentri data administratif dalam sistem. Data yang harus diisi diantaranya adalah penamaan perusahaan yang dimohonkan, rumpun investasi yang dituju, bentuk kegiatan perusahaan, tempat perusahaan, besaran dana yang diinvestasikan, ketika semua data selesai dimasukkan, sistem menelusuri data tersebut untuk dikonfirmasi. ${ }^{16}$ Langkah yang dilakukan untuk mengakses OSS antara lain :

a. Membuat user-ID;

b. Log-in ke sistem dari OSS dengan memakai user-ID yang telah dibuat;

c. memasukkan data yang dibutuhkan untuk memperoleh Nomor Induk Berusaha (NIB);

d. Bagi usaha baru: proses untuk memperoleh izin awal/dasar, bentuk izin usaha maupun izin untuk operasional dan komersial, beserta dengan pemenuhan komitmen berusahanya. Bagi usaha yang telah lama berdiri dengan cara melanjutkan proses untuk mendapatkan izin berusaha baik izin usaha dan izin komersial baru yang belum pernah didapat, menambah waktu izin berusaha yang telah dimiliki dengan memperpanjangnya, pengembangan bentuk usahanya, perubahan dan/ perbaikan data dasar perusahaan.

homebase data Direktorat Jenderal Administrasi Hukum Umum (AHU) Kementerian Hukum dan Hak Asasi Manusia langsung terintegarsi dengan Sistem OSS guna pengesahanan suatu bentuk badan usaha. Bentuk perseorangan, dalam sistem ini mengintegrasikan NIK serta mengkonfirmasi data Nomor Pokok Wajib Pajak dan identitas pemohon. Sistem ini juga memunculkan Nomor Induk Berusaha (NIB), BPJS sebagai bentuk integrasi pengamanan jarring kesehatan bagi buruh dan pegawainya, izin lokasi eksisting perusahaan, fasilitas fiskal kemudahan pajak, dan RPTKA sebagai pengurusan tenaga kerja asing yang tersedia dalam bentuk cloud data sehingga tidak

16 Kementerian Koordinator Bidang Perekonomian Republik Indonesia, 2018, Pedoman Perizinan Berusaha Melalui Sistem OSS Untuk Pelaku Usaha, Jakarta, h. 2 
perlu dua kali kerja menginput data kembali. Pada data dasar yang dientry, meliputi jangka waktu fiskal yang diperoleh, sistem akan memberikan informasi, "Perusahaan pemohon mendapatkan tax holiday 5 tahun" misalnya. Karena terkait fiskal, Kementerian Keuangan melalui Dirjen Pajak akan mengkonfirasi untuk dikeluarkannya surat keterangan bahwa pengusaha memperoleh tax holiday.

Surat konfirmasi tersebut dikuasai oleh pegawai dirjen pajak, Jika proses pendaftaran selesai, sistem secara otomatis akan membuat komitmen dengan pengusaha. Pemenuhan sertifikat laik fungsi untuk bangunan gedung harus dipenuhi dalam 3 hari, pemenuhan standar IMB dalam 30 hari, dan penerapan izin lingkungan berupa UKL-UPL untuk usaha yang berdampak besar harus selesai dalam 12 hari merupakan bentuk komitmen yang harus dipenuhi. Pengurusan izin secara offline bisa dilakukan bila PTSP daerah belum memiliki sistem online untuk jenis-jenis izin daerah. Izin Usaha Sektoral serta Surat Izin Usaha Perdagangan akan otomatis keluar jika semua pemenuhan komitmen selesai.

Selain itu, terkait investasi bidang kefarmasian dan kesehatan, dibutuhkan adanya komitmen terkait Cara Pembuatan Obat Yang Baik (CPOB) dan Cara Pembuatan Obat Tradisional yang Baik (СРOTB) dengan dimintakan pengurusan 35 hari serta Cara Pembuatan Alat Kesehatan yang Baik (CPAKB) dengan waktu permohonan selama 5 hari. Jika pemenuhan komitmen sudah terlaksana, maka segera dikeluarkan izin komersial atau izin operasional yaitu izin beredarnya obat dan sertifikasi kelayakan. Pada dasarnya, pemerintah percaya jika investor akan memenuhi komitmen pada perizinan tersebut. Namun apabila komitmen melebihi dari batas waktu yang telah ditentukan, maka izin yang telah diberikan dapat dicabut. Selain itu, melalui aplikasi OSS ini, investor dapat melakukan tracking system untuk memantau proses perizinan yang dimohonkan. Apabila ijinnya berhenti berproses di pemerintah daerah misalnya, maka ada Satuan Tugas (Satgas) yang akan menanganinya. Fungsi satgas ini sebagai tempat untuk mempercepat penyelesaian permasalahan-permasalahan terkait investasi dan perizinan. Satgas ini terdiri dari organisasai perangkat daerah teknis yang tergabung dalam satu wadah kesekretariatan. Jika terdapat permasalahan yang muncul akan dibahas dalam satgas ini, termasuk berhentinya proses perizinan. Dalam konteks ini, investor tidak perlu menunggu dan atau bertemu langsung dengan Pemerintah daerah atau kementerian untuk perijinan.

Pelayanan OSS pada Dinas Penanaman Modal dan PTSP di seluruh Indonesia diharapkan memberikan kemudahan, percepatan, akselerasi untuk menciptakan pelayanan prima kepada masyarakat. Kultur masyarakat Indonesia yang heterogen, dan kualitas sumber daya manusia yang berbeda perlu adanya inovasi dalam pelayanan OSS oleh penyelenggaran PTSP. Inovasi pelayanan OSS dapat diberikan penyelenggaran PTSP dalam 3 hal yaitu melalui pelayanan mandiri, pelayanan perbantuan, dan pelayanan Prioritas.

Pelayanan mandiri merupakan bentuk pelayanan kepada masyarakat/ pemohon sebagai subyek hukum penerima layanan dengan menyediakan Komputer di kantor layanan dan wifi gratis untuk mempermudah penerima layanan dalam mengakses sistem OSS. Setiap kantor PTSP harus menyediakan fasilitas ini, supaya masyarakat menerima kemudahan bagi mereka yang sudah paham teknologi informatika dan membutuhkan fasilitas perangkat komputer dan wifi untuk pengaksesan internet. Sedangkan pelayanan perbantuan, yaitu suatu layanan yang dibuka gerai khusus memberikan kemudahan layanan kepada masyarakat yang tidak begitu paham 
teknologi informatika. Pembuatan akun, mengakses OSS dan menginput data didamping oleh petugas dari PTSP. Terutama bagi pengusaha dalam skala kecil akan sangat mempermudah mereka, sehingga untuk pengusaha kecil dalam waktu beberapa menit menginput data, izin usaha yang meraka ajukan langsung dapat keluar. Percepatan ini sebagau azas kepastian hukum dalam berusaha, kepastian hukum yang dimaksud adalah negara hadir memberikan perlindungan usaha melalui legalitas atas bentuk usaha yang dilakukan oleh masyarakat.

Adapun pelayanan prioritas dibagi dalam beberapa layanan, diantaranya prioritas difabel, merupakan layanan pendampingan prioritas langsung diruang khusus untuk pengusaha difabel mulai dari pengurusan pengajuan akun OSS sampai berakhirnya izin usaha yang diminta. Prioritas berikutnya bagi ibu hamil dan orang lanjut usia, layanan ini sama diberikan bagi mereka dengan memberikan prioritas layanan berupa fasilitas-fasilitas pendampingan khusus. Prioritas yang terakhir adalah, memberikan prioritas pendampingan bagi calon pengusaha dengan modal usaha diatas 5 milyar, dimaksudkan bahwa bagi daerah berkembang sangat membutuhkan investasi, sehingga pengusaha besar ini menjadi skala priotitas layanan khusus. Harus disediakan ruangan khusus untuk melayani, sehingga calon investor ini merasa nyaman dan mendapatkan kemudahan. Investasi sangat berdampak pada pertumbuhan ekonomi suatu daerah maupun negara secara keseluruhan. Negara harus hadir terdepan untuk mengamankan dan memberikan kemudahan kepada calon investor besar. Sehingga kantor pemberi layanan lebih tanggap dan lebih mengetahui jenis usaha apa yang akan dijalankan.

Bentuk lain pemberian layanan kepada pelaku usaha bisa berupa kemudahan pengurangan pajak (tax clearance) dengan nilai investasi besar. Karena investasi besar juga berdampak pada sektor yang lainnya, terutama sektor ketenagakerjaan (banyak tenaga kerja yang akan terserap), dapat menaikkan pertumbuhan ekonomi dan sebagainya. Oleh karena itu, Pemerintah dituntut untuk lebih tanggap, responsif dan terbuka dalam memberikan layanan. Semakin cepat, mudah dan murah biaya yang dikeluarkan, maka calon investor akan lebih nyaman menanamkan modal usahanya.

\section{C.2. Akibat Hukum Bagi Pelaku Usaha Apabila Tidak Memenuhi Komitmen Berusaha}

Izin usaha merupakan suatu bentuk produk legal administrasi kepada perorangan maupun badan usaha dan badan hukum untuk memastikan usahanya, dengan memperoleh hak dan kewajibannya selaku subyek hukum. Pengurusan izin usaha sesuai dengan sampai ke tahap operasional membutuhkan pendaftaran akun melalui Online Single Submission. Setiap pemohon akan mendapatkan satu akun, dan diisi berdasarkan izin usaha yang akan dibuat. Setelah mengisi akun dan dinyatakan lengkap maka akan keluar NIB (Nomor Induk berusaha) untuk perorangan, badan usaha dan badan hukum yang terdaftar. Izin usaha dikatakan tuntas apabila, sudah mempunyai izin operasional untuk menjalankan usahanya, sebelum memiliki izin operasional pengusaha harus memenuhi komitmen izin usaha dan komitmen izin komersil. Peraturan Pemerintah Nomor 28 Tahun 2018 pasal 20 menyebutkan pelaksanaan izin berusaha meliputi :

a. Pendaftaran;

b. penerbitan Izin Usaha dan penerbitan Izin Komersial atau Operasional berdasarkan Komitmen; 
c. pemenuhan Komitmen lzin Usaha dan pemenuhan Komitmen Izin Komersial atau Operasional;

d. pembayaran biaya;

e. fasilitasi;

f. masa berlaku; dan

g. pengawasan.

Pada Pasal 40 peraturan ini menyebutkan "Lembaga OSS membatalkan lzin Usaha yang sudah diterbitkan dalam hal Pelaku Usaha tidak menyelesaikan pemenuhan Komitmen sebagaimana dimaksud dalam Pasal 32 dan/atau lzin Komersial atau Operasional sebagaimana dimaksud dalam Pasal 39". Semua perizinan usaha yang tidak memenuhi komitmen usaha dan komitmen komersil dibatalkan oleh lembaga OSS. Pemenuhan komitmen sebagai bentuk pengawasan terhadap suatu bentuk usaha. Persyaratan pemenuhan komitmen diantaranya berupa Izin Mendirikan Banguan (IMB), Izin Lingkungan, Izin Lokasi merupakan syarat mutlak untuk menyelesaikan izin sampai tahap operasional.

Contoh pemenuhan komitmen dalam suatu izin usaha adalah izin lingkungan, dalam pemenuhan komitmen izin lingkungan pemohon diberikan waktu selambatlambatnya 10 (sepuluh) hari sejak lembaga OSS mengeluarkan izin lokasi sebagaimana pasal 42 ayat 1 Peraturan ini. Apabila pemohon tidak mengajukan permohonan pemenuhan komitmen maka lembaga OSS membatalkan izin usaha yang dikeluarkan.

Perizinan merupakan suatu bentuk hukum administratif yang dikeluarkan oleh negara sebagi bentuk pengawasan dan fungsi control kepada bentuk kegiatan di masyarakat. Izin ini memberikan kepastian berusaha kepada para investor dalam menjalankan usahanya dengan mematuhi segala larangan dan kewajiban yang harus ditaati. Kemudahan dalam pengurusan perizinan merupakan salah satu indikator kemudahan pemberian pelayanan wajib kepada masyarakat. Izin harus berupa bentuk tertulis, sebagai bentuk sah apabila terjadi suatu permasalahan hukum, maka bisa dijadikan alat bukti di persidangan pada suatu sengketa hukum.

Komitemen berusaha sebagai janji pengusaha/investor untuk memperoleh izin akhir (operasinal dan produksi) yang didahului pengurusan izin usahanya. Janji ini mutlak harus dipenuhi, sebagai bentuk itikad baik dalam berusaha. Meyakini akan suatu hal bahwa apa yang mereka pahami dan ketahui adalah kebenaran, sehingga sudah sepatutnya pengusaha/investor harus menuruti dan mematuhinya (atau berpikir kebalikannya bahwa sesuatu hal yang salah, sudah seharusnya untuk tidak dipatuhi dan dilawan). ${ }^{17}$ Sanksi adminitratif terkait pengusaha/investor tidak dapat memenuhi komitmennya akan dicabut izin awalnya, dan apabila terdapat pelanggaran perizinan lingkungan akan dikenakan pidana lingkungan.

Negara menjamin kehidupan setiap warganya dan mempunyai kedudukan yang sama serta seimbang dimata hukum. Tugas negara diataranya menjamin kesejahteraan masyarakatnya (bestuurszorg), negara diberikan kewenangan pengaturan terkait sendi-sendi kehidupan. Sendi kehidupan diantaranya ekonomi, hukum, politik dan budaya. Pengaturan ini berbentuk kepastian, pelaksanaan, keteraturan dan ketetapan dalam kehidupan. Ketetapan dalam pengaturan kehidupan dalam hubungannya masyarakat dengan pemerintah ini berupa izin.

${ }^{17}$ Hadi Sutoyo, Komitmen Hukum dan Kritik Legalisme bagi Hakim, Varia Peradilan No. 293, 
Kepastian hukum bagi pelaku usaha ini memberikan pemahaman dalam mengambil keputusan untuk melangkah ke tahap selanjutnya. Persyaratan yang harus dipenuhi dalam keluarnya izin usaha saling berkaitan, baik dari segi perlindungan pada lingkungan, maupun sertifikasi pada bangunan yang akan dibangun, serta pengadaan sumber daya manusia. Pemenuhan komitmen menjadi suatu alat kontrol dari pemerintah, supaya ada keseimbangan antara memberikan izin usaha untuk meningkatkan ekonomi, tetapi juga adanya azas kepastian hukum dalam memberikan izin pada pelaku usaha.

Pelaku Usaha yang dibatalkan izin usahanya karena tidak memenuhi komitmen, apabila tidak dapat menerima keputusan itu bisa melaporkan ke Satgas dari tingkat nasional sampai daerah. Satgas berfungsi mempercepat proses perizinan, membimbing pelaku usaha, dan menyelesaikan permasalahan pengajuan izin usaha melalui OSS. Pelaku usaha juga dapat membuat gugatan kepada PTUN (Pengadilan Tata Usaha Negara) apabila ditemukan kejanggalan pembatal izin usaha yang tidak sesuai prosedur.

\section{KESIMPULAN}

Penataan perizinan berusaha oleh Pemerintah melalui kementerian/lembaga dan pemerintah daerah bertujuan untuk mendukung pelaksanaan dan pengembangan kegiatan usaha, dan bukan sebaliknya menjadi hambatan. Kesimpulan yang dapat ditarik adalah :

1. Penataan kembali perizinan berusaha diwujudkan dalam bentuk pelayanan, pengawalan (end to end), dan peran aktif penyelesaian hambatan pelaksanaan berusaha melalui pembentukan satuan tugas (Satgas) pada tingkat nasional, kementerian/lembaga, provinsi, dan kabupaten/kota. Sistem OSS mempermudah pengurusan perizinan berusaha dibandingkan sewaktu pengurusan perizinan secara manual (offline). Untuk mendukung kemudahan perizinan berusaha melalui sistem OSS, dapat dilakukan oleh pemerintah daerah dengan mengembangan sistem pelayanan mandiri, pelayanan pendampingan (perbantuan), maupun pelayanan prioritas dengan memberikan fasilitas pendukung bagi investor besar, penyandang difabel dan atau orang tua.

2. Pemenuhan Komiten menjadi syarat mutlak pemerintah sebagai fungsi pengawasan pada pelaku usaha, tetapi juga memberikan kepastian hukum melalui izin usaha yang dikeluarkan. Pelaku usaha yang tidak menyelesaikan komitemnya maka izin awalya akan dicabut, dan apabila komitmennya dipenuhi akan keluar izin operasional dan izin komersil.

\section{DAFTAR PUSTAKA}

Arfan Faiz Muhlizi, Penataan Regulasi Dalam Mendukung Pembangunan Nasional, Jurnal Rechtsvinding Vol. 6 No. 3, Badan Pembinaan Hukum Nasional, Jakarta, 2017

Aviliani, Mengurai Problema Investasi di Idonesia, Jurnal Diplomasi, Vol. 2 No. 2, Kementerian Luar Negeri, Jakarta, 2010

Desi Arianing Arum, Kepastian Hukum Dalam Perizinan Berusaha Terintegrasi Secara Elektronik (Online Single Submission) di Indonesia, Jurist-Diction Vol. 2 No. 5, September 2019, Universitas Airlangga, Surabaya

Galuh Wahyu Kumalasari, Penegakan Hukum Perizinan Sebagai Instrumen Penguatan Investasi sektor ekonomi Kreatif Guna Meningkatkan Kesejahteraan Masyarakat, Makalah Seminar Nasional dengan tema "Perizinan sebagai Instrumen Peningkatan Kesejahteraan 
Masyarakat di Era Industrialisasi" yang dilaksanakan Universitas Muhammadiyah Surakarta pada tanggal 29 April 2017

John Rawls, Teori Keadilan Dasar-Dasar Filsafat Politik untuk Mewujudkan Kesejahteraan Sosial dalam Negara, Pustaka Pelajar, Jakarta, 2019

Kementerian Koordinator Bidang Perekonomian Republik Indonesia, Pedoman Perizinan Berusaha Melalui Sistem OSS Untuk Pelaku Usaha, Jakarta, 2018

Philipus M. Hadjon, Pengantar Hukum Perizinan, Yuridika, Fakultas Hukum Universitas Airlangga, Surabaya, 1993

Salim HS dan Budi Sutrisno, Hukum Investasi di Indonesia, Raja Grafindo Persada, Depok, 2018

Muhammad Rustamaji, Menakar Pengawasan Pemberian Bantuan Hukum Dalam Pandangan Richard A Posner, Jurnal Rechtsvinding, Vol. 2 No. 1, April 2013, Badan Pembinaan Hukum Nasional, Jakarta, 2013. 